\title{
The association between the 844ins68 polymorphism in the $C B S$ gene and breast cancer
}

\author{
Martha Patricia Gallegos-Arreola ${ }^{1}$, Luis Eduardo Figuera-Villanueva², Adriana Ramos-Silva ${ }^{1,3}$, \\ Efraín Salas-González ${ }^{4}$, Ana María Puebla-Pérez ${ }^{5}$, Valeria Peralta-Leal' ${ }^{6}$, José Elías García-Ortiz², \\ Ingrid Patricia Dávalos-Rodríguez² ${ }^{2}$ Guillermo Moisés Zúñiga-González ${ }^{7}$
}

\begin{abstract}
${ }^{1}$ Laboratorio de Genética Molecular, División de Medicina Molecular, Centro de Investigación Biomédica de Occidente (CIBO), Centro Médico Nacional de Occidente (CMNO), Instituto Mexicano del Seguro Social (IMSS), Guadalajara, Jalisco, México 2División de Genética, CIBO, CMNO, IMSS, Guadalajara, Jalisco, México ${ }^{3}$ Doctorado en Farmacología, CUCS, UdeG, Guadalajara, Jalisco, México ${ }^{4}$ UMAE, Hospital de Gineco-Obstetricia, CMNO, IMSS, Guadalajara, Jalisco, México 'Laboratorio de Inmunofarmacología, CUCEI, UdeG, Guadalajara, Jalisco, México ${ }^{6}$ Facultad de Medicina e Ingeniería en Sistemas Computacionales (FMelSC), Universidad Autónoma de Tamaulipas, Matamoros, Tamaulipas, México 'Laboratorio de Mutagénesis, División de Medicina Molecular, CIBO, CMNO, IMSS, Guadalajara, Jalisco, México
\end{abstract}

Submitted: 28 November 2012

Accepted: 7 March 2013

Arch Med Sci 2014; 10, 6: 1214-1224

DOI: 10.5114 /aoms.2014.47830

Copyright @ 2014 Termedia \& Banach

\section{Abstract}

Introduction: The cystathionine beta synthase (CBS) gene plays an important role in homocysteine metabolism because it catalyzes the first step of the transsulfuration pathway, during which homocysteine is converted to cystathionine. Polymorphisms of CBS have been associated with cancer.

Material and methods: We examined the role of the 844ins68 polymorphism by comparing the genotypes of 371 healthy Mexican women with the genotypes of 323 Mexican women with breast cancer (BC).

Results: The observed genotype frequencies for controls and BC patients were $1 \%$ and $2 \%$ for Ins/Ins, $13 \%$ and $26 \%$ for $W / I n s$, and $86 \%$ and $72 \%$ for $\mathrm{W} / \mathrm{W}$, respectively. We found that the odds ratio (OR) was 2.2 , with a $95 \%$ confidence interval $(95 \% \mathrm{Cl})$ of $1.5-3.3, p=0.0001$. The association was also evident when comparing the distribution of the W/Ins-Ins/Ins genotypes in patients in the following categories: 1) menopause and high $\gamma$-glutamyltransferase (GGT) levels (OR of $2.17,95 \% \mathrm{Cl}: 1.17-4.26, p=0.02$ ), 2) chemotherapy response and high lactate dehydrogenase (LDH) levels (OR 2.2, $95 \% \mathrm{Cl}: 1.08-4.4, p=0.027), 3)$ chemotherapy response and high GGT levels (OR 2.46, 95\% Cl: $1.2-4.8, p=0.007)$, and 4 ) body mass index (BMI) and III-IV tumor stage (OR 3.2, 95\% Cl: 1.2-8.3, $p=0.013$ ).

Conclusions: We conclude that the genotypes W/Ins-Ins/Ins of the 844ins68 polymorphism in the $C B S$ gene contribute significantly to $B C$ susceptibility in the analyzed sample from the Mexican population.

Key words: 844ins68, T833C, polymorphism, breast cancer, Mexican population.

\section{Introduction}

Breast cancer (BC) is a disease characterized by the presence of uncontrolled cell growth in the ducts (ductal carcinoma) or lobules (lobular

\author{
Corresponding author: \\ Dr. en C. Martha Patricia \\ Gallegos-Arreola \\ División de Medicina \\ Molecular, \\ CIBO, IMSS \\ Sierra Mojada 800 \\ Col. Independencia \\ Guadalajara, Jalisco \\ 44340 (México) \\ Phone: +52 3336170060 \\ (31936) \\ E-mail: \\ marthapatriciagallegos08@ \\ gmail.com
}


carcinoma) of the mammary gland, and the tumor can invade the surrounding tissues of the breast in later stages. Most breast tumors are invasive or infiltrating, and they are classified by the American Joint Committee on Cancer (AJCC) by several defined stages [1]. Breast cancer is one of the most common diseases in developing countries in the world. It is estimated that there are millions of symptomatic women affected by $\mathrm{BC}$ and millions more currently asymptomatic who will develop cancer [2]. Incidence rates are variable in different ethnic groups with 122.6 per 100,000 cases in white women, 118 per 100,000 cases among blacks, 92.8 per 1000,000 cases in Hispanics, 87.9 per 100,000 cases in Asian/Pacific Islanders, and $65.6 \mathrm{per}$ 100,000 in American Indian/Alaskan Natives [3]. In many countries around the world, and particularity in Mexico, the incidence of $B C$ has increased within the last 6 years, and it is now one of the main causes of death in reproductive age females. The mortality incidence rate since 2006 has increased, and has surpassed the mortality rate of cervical cancer. The mortality rate in Mexico was 4,854 deaths in 2009 [4] and has been projected to increase to over 16,500 deaths per year by 2020 . Only $10 \%$ of all cases are detected at stage I. The state of Jalisco has one of the highest mortality rates for BC [5]. Breast cancer is considered to be a multifactorial disease, and BC might result from a combination of abnormal protein interactions and environmental factors [6]. Previous research has implicated a variety of risk factors for BC, including age, early menarche, menopause, oral contraceptive use, cigarette smoking, alcohol consumption, a family history of BC, breast fibrosis, nulliparity, breastfeeding, ethnicity, nutrition and genetics [7]. Elucidating the genetic variants among different ethnic groups could help to explain the progression of cancer, as well as chemotherapy response.

The CBS gene, which is located on chromosome 21q22.3, codes for an enzyme that participates in the folate pathway and catalyzes the transsulfu- ration of homocysteine and serine to cystathionine as a cysteine precursor [8]. CBS deficiency can modify the stability of a domain or residue in the hydrophobic core, which leads to degradation of the CBS protein. This produces elevated levels in the plasma of homocysteine and methionine, which consequently alter methylation processes [8]. Therefore, a CBS deficiency may have a potential impact on oncogenesis (Figure 1) [9].

The CBS gene has a large number of reported mutations and polymorphisms [8]. The 844ins68 polymorphism at position 844 in the CBS gene generates an alternative splicing site that disrupts the protein, which decreases the functional activity of CBS. This polymorphism was initially described in a homocystinuric patient [10]. The 844 ins68 polymorphism segregates in cis with the T833C mutation [11]. Different studies have found variability in the allelic frequency among ethnic groups, and homozygosity for the 68-bp insertion is rare in population studied [12]. Different populations have also shown variability in the frequency of the heterozygous genotype, with the highest prevalence of 66 at $20 \%$ being described in sub-Saharan African [13] and British populations [14]. The median prevalence of 17 at $11 \%$ was found in Brazil [9], Holland [15], Italy [16], Spain [17], Ethiopia [13], and the United States [11]. A low prevalence of the heterozygous genotype of 10 at $1 \%$ was observed in India [18], Czechoslovakia [19], South Iran [20], China [21], Colombia [22], and Chile [23]. The 844ins68 allele was not observed in Japan or Indonesia [13].

Although the biological impact of the 844ins68 polymorphism in the CBS gene is not clear, it has been associated with different pathologies, including cardiovascular defects, neural tube defects, and cancer [9, 12, 16, 17, 21, 22, 24, 25]. However, several of these studies that examined the connection between the 844ins68 polymorphism and $\mathrm{BC}$ did not reveal any statistically significant associations [26, 27].

\section{CBS gene}

$21 q 21.1$

$21 \mathrm{q} 21.3$

$21 \mathrm{q} 22.1$

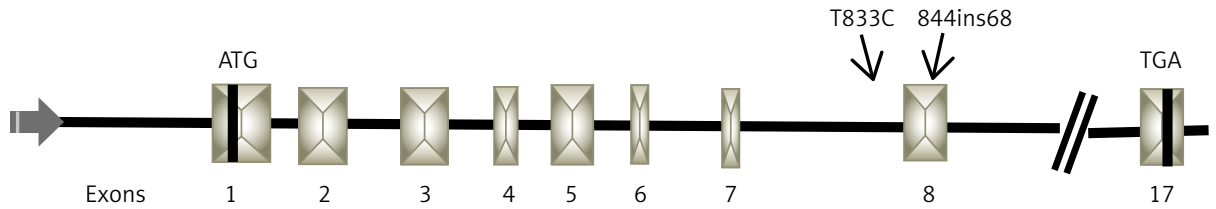

Figure 1. Schematic representation of CBS gene locus on 21 chromosome, indicating position of T833C (intron 7) and 844ins68 (exon 8) polymorphisms 
The aim of this study was to determine the association between the 844ins68 polymorphism in the CBS gene and Mexican women with $\mathrm{BC}$.

\section{Material and methods}

DNA was extracted from peripheral blood lymphocytes using standard protocols [28]. Blood samples were collected from 371 healthy women recruited as volunteer blood donors with an average age of 32.36 years. These volunteers were not matched by age with the patient group. Blood samples were also collected from 323 patients with clinical and histological confirmation of $\mathrm{BC}$, and all of the patients were residents of the metropolitan area of Guadalajara. The patients were recruited from June 2010 to April 2012. All of the samples were obtained with the appropriate written informed consent and approval from the ethical committee 1305, Centro de Investigación Biomédica de Occidente, IMSS. Efforts were taken to ensure that siblings of those already sampled were excluded. Clinical and demographical data were obtained using written questionnaires. All of the patients were also interviewed to determine occupational exposure and the use of therapeutics.

\section{Genotyping}

The amplification of exon 8 in the CBS gene was performed by PCR using the following primers: 5'-CTGGCCTTGAGCCCTGAA-3' derived from intron 7 and 5'-GGCCGGGCTCTGGACTC-3' derived from intron 8 [11]. The PCR reactions were performed in a total volume of $15 \mu \mathrm{l}$ containing $0.2 \mathrm{mM}$ dNTPs (Invitrogen, Carlsbad, CA USA), 5 pmol of primers, $3.0 \mathrm{mM} \mathrm{MgCl}, 2.5 \mathrm{U}$ Taq polymerase (Invitrogen, Carlsbad, CA USA), and 0.8\% bovine serum albumin (Promega, Madison, WI USA). The PCR conditions were $95^{\circ} \mathrm{C}(4 \mathrm{~min})$ followed by 30 cycles of $95^{\circ} \mathrm{C}(1 \mathrm{~min}), 60^{\circ} \mathrm{C}(1 \mathrm{~min})$, $72^{\circ} \mathrm{C}(2 \mathrm{~min})$ and a final extension at $72^{\circ} \mathrm{C}(7 \mathrm{~min})$. Using this procedure, we obtained fragments of 252 and 184 base pairs (bp). For 844ins68 allele discrimination, the amplified products were separated on $6 \%$ polyacrylamide gels $(29: 1)$ followed by silver staining [29]. We determined that the 184-bp fragment represented a wild-type genotype (W). Two fragments at 252 and 184-bp indicated a heterozygous genotype (W/Ins), and one fragment at 252-bp represented the genotype insertion of $68 \mathrm{bp}$ (Ins/Ins).

To determine whether the individuals with the $\mathrm{W} /$ Ins and Ins/Ins 844ins68 polymorphism genotypes carried the T833C mutation in the same allele, $2 \mu$ of the PCR products from intron 7 and exon 8 were subjected to restriction enzyme analysis with Bsrl (New England Biolabs, Beverly, MA, USA) according to the manufacturer's instructions, at $65^{\circ} \mathrm{C}$ for $12 \mathrm{~h}$. After electrophoresis on an $8 \%$ polyacrylamide gel $(19: 1)$, the product was visualized by silver staining [29], which revealed the presence of allele $833 \mathrm{C}$ with 209- and 184-bp fragments [11].

\section{Statistical analysis}

Allele frequencies were obtained by direct counting. The Hardy-Weinberg equilibrium was tested by a goodness-of-fit $\chi^{2}$ test to compare the observed genotype frequencies to the expected frequencies among control subjects. Odds ratios and $95 \%$ confidence intervals $(\mathrm{Cl})$ were also calculated. A two-sided $p<0.05$ was considered to be statistically significant. All statistical analyses were performed using PASW Statistic Base 18 software, 2009 (Chicago, IL).

\section{Results}

\section{Demographic characteristic of study groups}

Table I shows the comparative epidemiological data from the BC patients and the control individuals. In the patient group, the observed average age was 53.75 years, ranging from 28 to 88 years of age. Menarche had a mean age of 12.62 years in patients and 12.17 years in controls. Body mass index $(\mathrm{BMI}) \geq 30-34.9 \mathrm{~kg} / \mathrm{m}^{2}$ (crude $\mathrm{OR}=30.0$, $95 \% \mathrm{Cl}: 10.9-83.5, p<0.0001)$ and $\geq 35 \mathrm{~kg} / \mathrm{m}^{2}-$ $>40 \mathrm{~kg} / \mathrm{m}^{2}(\mathrm{OR}=12,95 \% \mathrm{Cl}: 5.0-32.5, p<0.0001)$, oral contraceptive use $(\mathrm{OR}=2.5,95 \% \mathrm{Cl}: 1.8-3.5$, $p<0.0001)$, breastfeeding ( $\mathrm{OR}=2.7,95 \% \mathrm{Cl}: 2.0-$ 3.7, $p<0.0001)$, menopause $(\mathrm{OR}=23.2,95 \% \mathrm{Cl}$ : 15.1-35.8, $p<0.0001)$, familial history (FH) (OR $=2.9,95 \% \mathrm{Cl}: 2.1-3.9, p<0.0001)$ and maternal familial history $(\mathrm{OR}=2.6,95 \% \mathrm{Cl}: 1.8-3.6, p<$ $0.0001)$ were presented as risk factors.

\section{Clinicopathological characteristics of BC patients}

Table II shows the general clinical characteristics of the patient group. We observed that $26 \%$ of the patients had breast fibrosis and arterial hypertension $(\mathrm{AH})$, approximately $40 \%$ were positive for hormonal receptors, $89 \%$ had ductal histology, and $62 \%$ had stage III-IV tumors. Approximately $20 \%$ of the patients had high levels of serum glutamate oxaloacetate transaminase (SGOT), alkaline phosphatase (ALP), GGT and glucose.

Table III summarizes the multivariate logistic regression analysis, where the $\mathrm{BC}$ group was classified as tumor stage I-II and III-IV as the dependent variables. The presence of menarche at $7-10$ years (adjusted $\mathrm{OR}=5.4,95 \% \mathrm{Cl}: 1.05-28.1, p=0.044$ ), tobacco consumption ( $\mathrm{OR}=2.5,95 \% \mathrm{Cl}$ : 1.1-5.7, $p=0.024$ ), chemotherapy (FEC, 5 -fluorouracil-epirubicin-cyclophosphamide) $(\mathrm{OR}=2.7,95 \% \mathrm{Cl}: 1.1-$ 
Table I. Demographic data of the study groups

\begin{tabular}{|c|c|c|c|c|c|c|}
\hline \multirow[t]{2}{*}{ Parameter } & \multicolumn{2}{|c|}{$\begin{array}{l}\text { Breast cancer } \\
\text { patients }\end{array}$} & \multicolumn{2}{|c|}{ Controls } & \multirow[t]{2}{*}{ OR $(95 \% \mathrm{Cl})$} & \multirow[t]{2}{*}{ Value of $p$} \\
\hline & $n=323$ & $\%$ & $n=371$ & $\%$ & & \\
\hline \multicolumn{7}{|l|}{ Age [years] } \\
\hline Mean (SD) & $(53.75)$ & 11.17 & $(32.36)$ & 9.57 & & $<0.0001^{1}$ \\
\hline \multicolumn{7}{|l|}{ Menarche [years] } \\
\hline Mean (SD) & $(12.62)$ & 1.6 & $(12.17)$ & 1.07 & & $<0.0001^{1}$ \\
\hline $7-10$ & $(20)$ & 6 & $(6)$ & 2 & $3.8(1.5-9.7)$ & 0.002 \\
\hline $11-13$ & $(213)$ & 66 & $(324)$ & 87 & $0.28(0.19-0.41)$ & $<0.0001$ \\
\hline $14-18$ & $(90)$ & 28 & $(41)$ & 11 & $2.65(1.7-3.9)$ & $<0.0001$ \\
\hline \multicolumn{7}{|l|}{ Body mass index $(\mathrm{BMI})^{*}\left[\mathrm{~kg} / \mathrm{m}^{2}\right]$ : } \\
\hline $18.5-24.9$ (normal) & (84) & 26 & $(202)$ & 55 & $0.29(0.21-0.40)$ & $<0.0001$ \\
\hline$\geq 25-29.9$ (overweight) & $(111)$ & 34 & $(160)$ & 43 & $0.69(0.50-0.93)$ & 0.018 \\
\hline$\geq 30-34.9$ (obesity I) & (80) & 25 & $(4)$ & 1 & $30(10.9-83.5)$ & $<0.0001$ \\
\hline$\geq 35->40$ (obesity II-III) & $(48)$ & 15 & $(5)$ & 1 & $12(5.0-32.5)$ & $<0.0001$ \\
\hline \multicolumn{7}{|l|}{ Oral contraceptive use: } \\
\hline Yes & $(147)$ & 46 & $(91)$ & 25 & $2.5(1.8-3.5)$ & $<0.0001$ \\
\hline No & $(176)$ & 54 & $(280)$ & 75 & & \\
\hline \multicolumn{7}{|l|}{ Breastfeeding: } \\
\hline Yes & $(215)$ & 66 & $(155)$ & 42 & $2.7(2.0-3.7)$ & $<0.0001$ \\
\hline No & (108) & 34 & $(216)$ & 58 & & \\
\hline \multicolumn{7}{|l|}{ Menopause: } \\
\hline Postmenopausal & $(222)$ & 69 & (32) & 9 & $23.2(15.1-35.8)$ & $<0.0001$ \\
\hline Premenopausal & $(101)$ & 31 & (339) & 91 & & \\
\hline \multicolumn{7}{|l|}{ Tobacco consumption: } \\
\hline Yes & $(80)$ & 25 & $(80)$ & 22 & & 0.317 \\
\hline No & $(243)$ & 75 & $(291)$ & 78 & & \\
\hline \multicolumn{7}{|l|}{ Alcohol consumption: } \\
\hline Yes & (64) & 20 & $(95)$ & 26 & & 0.07 \\
\hline No & $(259)$ & 80 & $(276)$ & 74 & & \\
\hline \multicolumn{7}{|l|}{ Familial history $(\mathrm{FH})^{\star \star}$ : } \\
\hline Yes & (198) & 61 & $(132)$ & 36 & $2.9(2.1-3.9)$ & $<0.0001$ \\
\hline No & $(125)$ & 39 & (239) & 64 & & \\
\hline \multicolumn{7}{|l|}{ Cancer type of FH: } \\
\hline No & $(125)$ & 39 & $(239)$ & 64 & $0.3(0.25-0.47)$ & $<0.0001$ \\
\hline Breast cancer & $(41)$ & 13 & $(16)$ & 4 & $3.2(1.7-5.8)$ & $<0.0001$ \\
\hline Cancer + breast cancer & $(30)$ & 9 & $(30)$ & 8 & & 0.57 \\
\hline Diabetes mellitus (DM) & $(27)$ & 8 & $(56)$ & 15 & $0.51(0.31-0.83)$ & 0.006 \\
\hline Arterial hypertension $(\mathrm{AH})$ & $(6)$ & 2 & $(29)$ & 8 & $0.22(0.09-0.54)$ & 0.0003 \\
\hline DM-AH & $(21)$ & 7 & $(0)$ & 0 & $8.1(1.0-66.9)$ & 0.019 \\
\hline DM-AH-cancer & (73) & 22 & $(1)$ & 1 & $108(14.9-782)$ & $<0.0001$ \\
\hline \multicolumn{7}{|l|}{ Inheritance: } \\
\hline No & $(125)$ & 39 & $(239)$ & 65 & $0.3(0.25-0.47)$ & $<0.0001$ \\
\hline Maternal & $(125)$ & 39 & $(72)$ & 19 & $2.6(1.8-3.6)$ & $<0.0001$ \\
\hline Paternal & (33) & 10 & $(36)$ & 10 & & 0.82 \\
\hline Both & $(40)$ & 12 & $(24)$ & 6 & $2.0(1.2-3.4)$ & 0.007 \\
\hline
\end{tabular}

${ }^{1}$ Fisher's exact test. SD, standard deviation. *According to OMS classifications (Appropriate body mass index for Asian populations and its implications for policy and intervention strategies. Ginebra (Suiza): Organización Mundial de la Salud, 2004). **Positive familial history of cancer and leukemia in first and second degree relatives of patients. 
M.P. Gallegos-Arreola, L.E. Figuera-Villanueva, A. Ramos-Silva, E. Salas-González, A.M. Puebla-Pérez, V. Peralta-Leal, J.E. García-Ortiz, I.P. Dávalos-Rodríguez, G.M. Zúñiga-González

Table II. Clinical data of patients with breast cancer

\begin{tabular}{|c|c|c|c|c|c|}
\hline \multirow[t]{2}{*}{ Parameter } & \multicolumn{2}{|c|}{ Breast cancer } & \multirow[t]{2}{*}{ Parameter } & \multicolumn{2}{|c|}{ Breast cancer } \\
\hline & $n=323$ & $\%$ & & $n=323$ & $\%$ \\
\hline \multicolumn{3}{|l|}{ Personal medical history: } & \multicolumn{3}{|l|}{ Chemotherapy type: } \\
\hline No & 173 & 53 & FEC & 264 & 82 \\
\hline $\mathrm{DM}-\mathrm{AH}$ & 83 & 26 & Other & 45 & 14 \\
\hline Breast fibrosis-AH & 21 & 7 & No chemotherapy & 14 & 4 \\
\hline Hysterectomy, AH & 28 & 9 & \multicolumn{3}{|l|}{ Chemotherapy toxicity: } \\
\hline \multirow{2}{*}{$\begin{array}{l}\text { Depression, pregnancy, } \\
\text { preeclampsia }\end{array}$} & \multirow[t]{2}{*}{5} & \multirow[t]{2}{*}{1} & Yes & 255 & 79 \\
\hline & & & No & 68 & 21 \\
\hline Thrombosis & 7 & 2 & \multirow{2}{*}{\multicolumn{3}{|c|}{$\begin{array}{l}\text { Laboratory test: } \\
\qquad \text { Hemoglobin [g/dl]: }\end{array}$}} \\
\hline Hyperthyroidism & 6 & 2 & & & \\
\hline \multicolumn{3}{|l|}{ Tumor localization: } & $<11$ & 27 & 8 \\
\hline Right/left & 311 & 96 & $11-16.4$ & 296 & 92 \\
\hline Bilateral & 12 & 4 & \multicolumn{3}{|l|}{ Hematocrit (\%): } \\
\hline \multicolumn{3}{|l|}{ BI-RADS } & $<37$ & 58 & 18 \\
\hline Grade IV & 239 & 75 & $37-47$ & 265 & 82 \\
\hline Grade V & 84 & 26 & \multicolumn{3}{|l|}{ Platelets $\left[\mathrm{mm}^{3}\right]$ : } \\
\hline \multicolumn{3}{|l|}{ Diagnostic time [years]: } & $<450,000$ & 20 & 6 \\
\hline $1-4$ & 215 & 67 & $150,000-450,000$ & 208 & 64 \\
\hline $5-9$ & 100 & 31 & $>450,000$ & 95 & 30 \\
\hline $10-15$ & 8 & 2 & \multicolumn{3}{|l|}{ Leukocytes $\left[\mathrm{mm}^{3}\right]$ : } \\
\hline \multicolumn{3}{|l|}{ Tumor markers: } & $<150,000$ & 35 & 11 \\
\hline Luminal A & 140 & 43 & $150,000-500,000$ & 288 & 89 \\
\hline Luminal B & 86 & 27 & \multicolumn{3}{|l|}{ Urea [mg/dl]: } \\
\hline Triple negative & 53 & 16 & $>20$ & 44 & 14 \\
\hline Her 2-neu & 44 & 14 & $6-20$ & 279 & 86 \\
\hline \multicolumn{3}{|l|}{ Histology: } & \multicolumn{3}{|l|}{ Creatine $[\mathrm{mg} / \mathrm{dl}]$ : } \\
\hline Ductal & 288 & 89 & $>1.1$ & 17 & 5 \\
\hline Lobular & 28 & 9 & $3-1.1$ & 306 & 95 \\
\hline Mixed & 7 & 2 & Serum glutamate-oxa & ransamina & SGOT) \\
\hline \multicolumn{3}{|l|}{ Tumor stage: } & {$[\mathrm{ml} / \mathrm{l}]:$} & 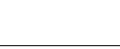 & 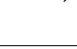 \\
\hline$|-| \mid$ & 122 & 38 & $>35$ & 68 & 21 \\
\hline III-IV & 201 & 62 & $0-35$ & 255 & 79 \\
\hline Lymph node status: & & & Serum glutamic pyruv & inase (SGP & $\mu \mathrm{l} / \mathrm{l}]:$ \\
\hline Yes & 241 & 75 & $>45$ & 53 & 16 \\
\hline No & 82 & 25 & $5-45$ & 270 & 84 \\
\hline Metastasis: & & & Lactate dehydrogenas & /l]: & \\
\hline Yes & 95 & 29 & $>333$ & 60 & 19 \\
\hline No & 228 & 71 & $105-333$ & 263 & 81 \\
\hline Metastasis site $(n=95)$ & & & Alkaline phosphatase & & \\
\hline Lung & 7 & 7 & $>45$ & 69 & 21 \\
\hline Bone & 47 & 49 & $5-45$ & 254 & 79 \\
\hline Liver & 3 & 3 & $\gamma$-Glutamyltransferase & & \\
\hline Bone-lung-liver & 36 & 39 & $>45$ & 70 & 22 \\
\hline Lung-central nervous system & 2 & 2 & $5-45$ & 253 & 78 \\
\hline Chemotherapy response: & & & Glucose $[\mu \mathrm{I} / \mathrm{l}]$ & & \\
\hline Yes & 223 & 69 & 74-106 & 65 & 20 \\
\hline No & 100 & 31 & $>106$ & 258 & 80 \\
\hline
\end{tabular}

FEC - 5-fluorouracil, epirubicin, cyclophosphamide, others - paclitaxel, docetaxel, trastuzumab. 
Table III. The regression binary logistic of the breast cancer group

\begin{tabular}{|lcccccccc|}
\hline & B & SD & Wald & $\mathrm{d} f$ & $\begin{array}{c}\text { Value } \\
\text { of } p\end{array}$ & OR & \multicolumn{2}{c|}{$95 \% \mathrm{Cl}$} \\
\cline { 7 - 10 } & & & & & & & Low & Upper \\
\hline Menarche (7-10 years) & 1.692 & 0.839 & 4.068 & 1 & 0.044 & 5.430 & 1.049 & 28.114 \\
\hline No oral contraceptive use & -0.743 & 0.337 & 4.864 & 1 & 0.027 & 0.476 & 0.246 & 0.921 \\
\hline Tobacco (consumption) & 0.937 & 0.415 & 5.096 & 1 & 0.024 & 2.552 & 1.131 & 5.756 \\
\hline Familial history (absence) & -1.407 & 0.595 & 5.582 & 1 & 0.018 & 0.245 & 0.076 & 0.787 \\
\hline Chemotherapy (FEC) & 1.009 & 0.450 & 5.023 & 1 & 0.025 & 2.743 & 1.135 & 6.627 \\
\hline Lymph node status & 1.054 & 0.386 & 7.461 & 1 & 0.006 & 2.869 & 1.347 & 6.112 \\
\hline Constant & 67.03 & 70843 & 0.000 & 1 & 0.999 & 1.293 & & \\
\hline
\end{tabular}

Variables included in the analysis: dependent: breast cancer patients classified by tumor status as I-II and III-IV. Independent: personal medical history, menarche ranges 7-10 years, 11-13 years, 14-18 years; menopause, pregnancies, breastfeeding, oral contraceptive use, tobacco and alcohol consumption, HF, HF type: breast cancer, DM, AH, DM-AH-cancer, parental inheritance: mother, father, both, and BMI: $18.5-24.9, \geq 25-29.9, \geq 30-34.9, \geq 35->40 \mathrm{~kg} / \mathrm{m}^{2}$, years of diagnosis; BI-RADS, histology, tumor markers, lymph node status, metastasis, MTS tissue, response to chemotherapy, type of chemotherapy, toxicity in chemotherapy, laboratory tests (HB, HTO, platelets, leukocytes, urea, creatinine, SGOT, SGPT, LDH, ALP, GGT and glucose).

Table IV. Genotype and allelic distribution of the 844ins68/T833C CBS polymorphism ${ }^{\star *}$ in healthy controls and breast cancer patients

\begin{tabular}{|lccccccc|}
\hline Genotypes & \multicolumn{8}{c|}{ Groups } \\
\cline { 2 - 9 } & \multicolumn{1}{c}{ Patients $(n=323)$} & Controls* $(n=371)$ & \multicolumn{3}{c|}{ Patients vs. controls } \\
\cline { 2 - 8 } & $n$ & $\%$ & $n$ & $\%$ & OR & $95 \%$ Cl & Value of $p$ \\
\hline W/W & 233 & 72 & 320 & 86 & 0.41 & $0.28-0.60$ & 0.001 \\
\hline W/Ins & 83 & 26 & 49 & 13 & 2.2 & $1.5-3.3$ & 0.0001 \\
\hline Ins/Ins & 7 & 2 & 2 & 1 & 4.0 & $0.84-19.8$ & 0.05 \\
\hline W/Ins and Ins/Ins & 90 & 28 & 51 & 14 & 2.4 & $1.6-3.5$ & 0.0001 \\
\hline Alleles: & & & & & & & \\
\hline W & 549 & 0.85 & 689 & 0.93 & 0.43 & $0.30-0.61$ & 0.0001 \\
\hline Ins & 97 & 0.15 & 53 & 0.07 & 2.2 & $1.6-3.2$ & 0.0001 \\
\hline
\end{tabular}

${ }^{*}$ Hardy-Weinberg equilibrium in the controls $\left(X^{2}=0.015 ; p=0.90\right) ;{ }^{*}$ Marker informativity 0.87 was assessed within a range of $0-1$ : markers with a score greater than 0.7 were considered to be highly informative, whereas markers with a value of 0.44 were considered to be moderately informative [6].

6.6, $p=0.025)$ and nodule metastatic $(\mathrm{OR}=2.8$ $95 \% \mathrm{Cl}: 1.3-6.1, p=0.006)$ were risk factors. In contrast, not using oral contraceptives $(\mathrm{OR}=0.47$, 95\% Cl: $0.24-0.92, p=0.027)$ and the absence of a familial history of cancer $(\mathrm{OR}=0.24,95 \% \mathrm{Cl}$ : $0.07-0.78, p=0.018$ ) were protection factors.

\section{Frequency of 844ins 68 polymorphism of $C B S$ gene between study groups}

Co-segregation of the 844ins68 and T833C polymorphisms were observed in the controls and patient groups. For that reason, we just present the 844 ins 68 polymorphism data in Table IV. The W/W genotype was observed in $72 \%(233 / 323)$ of patients compared with $86 \%(320 / 371)$ of the controls $(\mathrm{OR}=0.41,95 \% \mathrm{Cl}: 0.28-0.60, p=0.001)$. The heterozygous genotype (W/Ins) was observed in $26 \%$ of the patients (83/323) and $13 \%(49 / 371)$ of the controls $(\mathrm{OR}=2.2,95 \% \mathrm{Cl}: 1.5-3.3, p=$ $0.0001)$. The polymorphic genotype (Ins/Ins) was observed in $2 \%(7 / 323)$ of the controls and in $1 \%(2 / 371)$ of the patients $(p=0.05)$. All of the genotype distributions were in Hardy-Weinberg equilibrium. All of the samples were analyzed, and all of the genotypes ( 373 controls and 232 BC patients) were obtained. In addition, no differences were found with regard to the general characteristics of the study groups and 844ins68/ T833C CBS polymorphisms, except that the absence of metastatic lymph was associated with the genotype $\mathrm{W} / \mathrm{W}(\mathrm{OR}=0.430,95 \% \mathrm{Cl}: 0.21-0.85, p=0.015)$ as a protective factor.

\section{Comparison between heterozygous genotype patients with clinical-pathologic characteristics of $\mathrm{BC}$ patients}

Table $V$ shows that the patients with the heterozygous genotype were associated with more than one variable listed in Table I and II. The heterozygous patients who had undergone menopause 
M.P. Gallegos-Arreola, L.E. Figuera-Villanueva, A. Ramos-Silva, E. Salas-González, A.M. Puebla-Pérez, V. Peralta-Leal, J.E. García-Ortiz, I.P. Dávalos-Rodríguez, G.M. Zúñiga-González

Table V. Association of the 844ins68/T833C CBS polymorphism with more than one variable of the general characteristics of the breast cancer patients

\begin{tabular}{|c|c|c|c|c|c|c|}
\hline \multirow[t]{2}{*}{ Variable } & \multirow[t]{2}{*}{ Polymorphism } & \multicolumn{4}{|c|}{ Menarche (7-10 years) } & \multirow[t]{2}{*}{ Value of $p$} \\
\hline & & Yes, $n$ & No, $n$ & OR & $95 \% \mathrm{Cl}$ & \\
\hline \multirow[t]{2}{*}{ Menopause } & W/Ins-Ins/Ins & 3 & 21 & 10.85 & $(1.07-109.8)$ & 0.040 \\
\hline & W/W & 1 & 76 & & & \\
\hline \multicolumn{7}{|c|}{ GGT levels } \\
\hline & & High & Normal & & & \\
\hline & W/Ins-Ins/Ins & 20 & 46 & 2.17 & $(1.1-4.26)$ & 0.02 \\
\hline & W/W & 26 & 130 & & & \\
\hline \multicolumn{7}{|c|}{ Alcohol consumption } \\
\hline Tumor stage & & Yes & No & & & \\
\hline \multirow[t]{2}{*}{$|-| \mid$} & W/Ins-Ins/Ins & 9 & 18 & 3.1 & $(1.17-8.49)$ & 0.019 \\
\hline & W/W & 13 & 82 & & & \\
\hline \multicolumn{7}{|c|}{ Diagnostic [years] } \\
\hline \multicolumn{2}{|c|}{ Chemotherapy response } & $5-9$ & $1-4$ & & & \\
\hline & W/Ins-Ins/Ins & 24 & 39 & 1.97 & $(1.05-3.69)$ & 0.031 \\
\hline & W/W & 38 & 122 & & & \\
\hline \multicolumn{7}{|c|}{ LDH serum levels } \\
\hline & & High & Normal & & & \\
\hline & W/Ins-Ins/Ins & 17 & 46 & 2.2 & $(1.08-4.47)$ & 0.027 \\
\hline & W/W & 23 & 137 & & & \\
\hline \multicolumn{7}{|c|}{ GGT levels } \\
\hline & & High & Normal & & & \\
\hline & W/Ins-Ins/Ins & 21 & 42 & 2.46 & $(1.2-4.8)$ & 0.007 \\
\hline & W/W & 27 & 133 & & & \\
\hline \multicolumn{7}{|c|}{ Diagnosis [years] } \\
\hline BMI & & $5-9$ & $1-4$ & & & \\
\hline \multirow[t]{2}{*}{$\geq 30->40$} & W/Ins-Ins/Ins & 26 & 34 & 2.07 & $(1.1-3.86)$ & 0.021 \\
\hline & W/W & 41 & 111 & & & \\
\hline \multicolumn{7}{|c|}{ Tumor stage } \\
\hline & & III-IV & $I-I I$ & & & \\
\hline & W/Ins-Ins/Ins & 23 & 7 & 3.2 & $(1.2-8.3)$ & 0.013 \\
\hline & $\mathrm{W} / \mathrm{W}$ & 41 & 40 & & & \\
\hline
\end{tabular}

were associated with menarche (7-10 years) (OR $=10.85,95 \% \mathrm{Cl}: 1.07-109.8, p=0.040)$ and elevated levels of the enzyme GGT $(\mathrm{OR}=2.17$, $95 \% \mathrm{Cl}: 1.1-4.26, p=0.02)$ as risk factors.

The heterozygous patients with stage I-II tumors were associated with alcohol consumption $(\mathrm{OR}=3.1,95 \% \mathrm{Cl}: 1.17-8.49, p=0.019)$. The heterozygous patients who responded to chemotherapy showed an association with the following: 1 ) the diagnosis of $5-9$ years $(\mathrm{OR}=1.97,95 \% \mathrm{Cl}$ : $1.05-3.69, p=0.031)$, high levels of LDH (OR = 2.2, 95\% Cl: 1.08-4.47, $p=0.027)$, and high levels of GGT (OR $=2.4,95 \% \mathrm{Cl}: 1.2-4.8, p=0.007)$. Heterozygous patients with a BMI of $18.5-30 \mathrm{~kg} / \mathrm{m}^{2}$ 
and $\geq 30 \mathrm{~kg} / \mathrm{m}^{2}->40 \mathrm{~kg} / \mathrm{m}^{2}$ were associated with the diagnosis of $5-9$ years $(O R=2.07$, $95 \% \mathrm{Cl}: 1.1-3.86, p=0.021)$, and tumor stage III-IV $(\mathrm{OR}=3.2,95 \% \mathrm{Cl}: 1.2-8.3, p=0.013)$.

\section{Discussion}

In Mexico, BC is considered to be a major health population issue because it is currently one of the leading causes of death in productive age women $[4,5]$. These facts are consistent with our observations in the current study, wherein the average age was $53.75 \pm 11.17$, early menarche (7-10 years), BMI obesity II-III ( $\geq 30 \mathrm{~kg} / \mathrm{m}^{2}$ to $>40 \mathrm{~kg} / \mathrm{m}^{2}$ ), menopause status, familial history of cancer, diabetes mellitus (DM) and hypertension were observed as risk factors. These observations have been observed in other reports [30-36]. Breastfeeding was recorded in $66 \%$ of the patients in contrast with $42 \%$ of the controls, which made it a risk factor. However, these results should be taken with caution, because they did not consider the period of lactation. It is hypothesized that prolonged breastfeeding reduces the risk of $\mathrm{BC}$, and that risk is reduced by $4 \%$ for each 12 months of breastfeeding [37]. One study estimated that approximately $3 \%$ of breast cancers in UK women were associated with breastfeeding for less than 6 months [38].

When the BC group was stratified by tumor stage, as either I-II or III-IV, and compared with the clinical and biochemical characteristics of BC, early menarche (7-10 years), contraceptive hormonal use, familial history, tobacco consumption, metastasis to lymph nodes, and chemotherapy type (FEC) emerged as risk factors. The association of tobacco use with $\mathrm{BC}$ is still controversial, and one study showed that smokers had a $B C$ risk of $10-20 \%$ compared to nonsmokers [38-40]. This association depends on the number of cigarettes smoked per day and exposure time; however, in most studies, these parameters are not considered. In this regard, in our study, patients with stage III-IV tumors who smoked had increased risk, and our data are consistent with previous reports $[39,40]$. Also, the presence of lymph node metastases and chemotherapy type were risk factors for BC patients with stage III-IV tumors. In fact, the BC tumor stage is important for determining treatment, and a predictor of survival. There is evidence that patients with micrometastases in axillary lymph nodes have an increased risk of distant metastases compared to patients without axillary lymph node metastases [39].

Among factors that can favor carcinogenesis are individual genetic variations for susceptibility. Polymorphisms, which are low penetrance genes, are risk factors in cancer [40-44]. Folate metabolism has been proposed to be a contributing factor, by promoting DNA hypomethylation of key regulatory genes and uracil misincorporation into DNA, which leads to double-strand breaks and chromosomal aberrations [45]. The biochemical effect of the 844ins68 polymorphism has been associated with either low levels of homocysteine and methionine [46, 47], or high levels of homocysteine [48] when it co-segregates in cis with T833C [46-49]. Our findings are consistent with co-segregation because we observe similar frequencies of both the 844ins 68 and the T833C polymorphisms. In the literature, several population frequencies of 844ins68 have been published [12-25]. Little is known about the association of this polymorphism with $B C$ in our population; the allelic frequency of this polymorphism was 0.07 in controls and 0.15 in BC patients and was associated as a risk factor. However, a study observed the association between 844ins68 polymorphism with lower survival in neck cancer [49].

A possible explanation could be that CBS enzyme catalyzes the condensation of homocysteine with serine to give rise to cystathionine as a precursor of cysteine. The CBS deficiency can alter the stability of a domain or residue in the hydrophobic core, which leads to degradation of the protein and produces elevated plasma homocysteine and methionine leading to genomic DNA hypomethylation [50]. This may potentially have an impact on $\mathrm{BC}$ oncogenesis.

Although the sample representing the association of the W/Ins-Ins/Ins genotype, as a risk factor in postmenopausal patients presenting early menarche, was small, this association was observed in this study, and probably both prolonged exposure to estrogens and nutritional status could be the explanation; however, there is no evidence in the literature of this association. Another possible explanation is that given folates are involved in DNA methylation [9, 44], variations in genes of this pathway, such as the CBS gene, may cause poor metabolism of folate and may alter DNA methylation patterns and influence the expression, integrity and stability of DNA [9]. Moreover, alteration in the levels of folate may have an effect on other metabolic pathways, such as the estrogen pathway. Zhu et al. postulated that a folate and methionine deficiency may be associated with BC because of methylation of the estrogen receptor gene's CpG islands [51]; this finding is related to the lack of gene expression in breast tumors that are positive for the estrogen receptor.

We also observed the association of the W/InsIns/Ins genotype in postmenopausal patients with elevated levels of GGT as a risk factor. This observation could possibly be explained by the participation of GGT in cellular glutathione metabolism, modulated redox reactions and its reconstitution 
of cellular antioxidant, antitoxic defense, cell proliferation, apoptosis, tumor progression, invasion and cancer cell drug resistance. The expression of GGT is often increased in tumors and has been suggested to be a biomarker [52-54]. The GGT enzyme is expressed constitutively in various organs and rises significantly in premalignant lesions or malignant tumors; therefore, it is considered to confer a favorable environment for the growth and survival of neoplastic cells [52]. This study provides new data for alcohol consumption as a risk factor, because of the observed association between the W/Ins-Ins/Ins CBS genotype in BC with tumor stage $I-I$ and alcohol consumption. It is known that alcohol increases the endogenous levels of estrogen, which is a known risk factor for BC [55].

The response to chemotherapy in $\mathrm{BC}$ patients with evolution from 5 to 9 years and elevation of LDH and GGT enzymes were influenced by the W/Ins-Ins/Ins CBS genotype in this study; but it is well known that the response to chemotherapy depends on several factors. Adjuvant chemotherapy can induce persistent resistance to the drugs with longer exposure, and the anthracyclines have achieved longer time to progression and survival time compared with cyclophosphamide/methotrexate/5-fluorouracil-based chemotherapy [56].

In contrast, it has been observed that high expression of $\mathrm{LDH}$ and GGT is indicative of a poor response in patients with $B C$ at later stages. The elevated expression of these enzymes is thought to reflect tumor aggressiveness [57]. Another factor that may influence the response to chemotherapy is menopause, which is associated with a less favorable response [58]. However, there are no studies concerning the influence of the W/Ins-Ins/Ins CBS genotype and the response to chemotherapy depending on the overexpression of the $\mathrm{LDH}$ and GGT enzymes.

The $\mathrm{W} /$ Ins-Ins/Ins genotype is a risk factor in $B C$ patients with a BMI $\geq 29.9 \mathrm{~kg} / \mathrm{m}^{2}->40 \mathrm{~kg} / \mathrm{m}^{2}$ who were diagnosed in 5 to 9 years, have advanced tumor stage (III-IV) and have an inherited family history. Obesity is a major risk factor for developing $B C$ in postmenopausal women. Weight gain in women with postmenopausal BC in industrialized countries has a significant impact on health [59]. Several studies have reported that women who are obese at diagnosis have an increased risk of lymph node metastasis [60]. In fact, there are several theories that attempt to explain this association, involving the role of leptin, insulin and other molecules that mediate the inflammatory process independently of estrogen. In addition, peripheral circulating estrogens are elevated in obese postmenopausal women. Another current hypothesis proposes that obesity is associated with metabolic syndrome, which activates molecular processes that are mitogenic in breast epithelial cells and stimulate neoplasia. A third proposal suggests that adipocytes and their autocrine mechanisms are important for BC development [32].

Several hypotheses have been proposed to try to explain this association, which influences growth and BC prognosis. It has been suggested that adipocytes are now recognized as active endocrine cells that produce hormones, growth factors and cytokines. In fact, the most likely scenario is that all of these mechanisms may combine to explain the relationship linking menopause and subsequent weight gain in BC [60-62].

In conclusion, the 844ins68/T833C CBS polymorphism contribute significantly to BC susceptibility in: 1) menopause and high GGT levels, 2) chemotherapy type and high LDH levels, 3) chemotherapy type and high GGT levels, and 4) BMI and III-IV tumor stage, in the analyzed sample from the Mexican population, but further studies are required to confirm or reject these observations.

\section{Acknowledgments}

This studied was supported by grand from FIS/ IMSS/PROT/G13/1231.

\section{References}

1. Bandi MS, Brinton L, Buchert S, et al. Breast cancer facts and figures 2009-2010. American Cancer Society, [http://www.cancer.org/acs/groups/content/@nho/ documents/document/f861009final90809pdf.pdf]

2. Siegel R, Desantis C, Virgo K, et al. Cancer treatment and survivorship statistics, 2012. CA Cancer J Clin 2012; 62: 220-241.

3. Miller JW, King JB, Joseph DA, Richardson LC. Breast cancer screening among adult women - behavioral risk factor surveillance system, United States, 2010. MMWR Surveill Summ 2012; 61: 46-50.

4. Mortalidad de cáncer de mama: [http://www.cnegsr. gob.mx/programas/cancer-mama/mortalidad-cancer-de-mama.html

5. Knaul FM, Nigenda G, Lozano R, Arreola H, Langer A, Frenk J. Breast cancer in Mexico: an urgent priority. Salud Publica Mex 2009; 51 (Suppl. 2): 335-44.

6. Gallegos MP, Valencia LE, Puebla AM, Figuera LE, Zúñiga GM. The TP53 16-bp duplication polymorphism is enriched in endometriosis patients. Gynecol Obstet Invest 2012; 73: 118-23.

7. Abdulrahman GO Jr, Rahman GA. Epidemiology of breast cancer in Europe and Africa. J Cancer Epidemiol 2012; 2012: 915610.

8. Kraus JP, Oliveriusova J, Sokolova J, et al. The human cystathionine beta-synthase (CBS) gene: complete sequence, alternative splicing, and polymorphisms. Genomics 1998; 52: 312-24.

9. Galbiatti AL, Ruiz MT, Raposo LS, Maniglia JV, Pavarino-Bertelli EC, Goloni-Bertollo EM. The association between CBS 844ins68 polymorphism and head and neck squamous cell carcinoma risk - a case-control analysis. Arch Med Sci 2010; 6: 772-9.

10. Sebastio G, Sperandeo MP, Panico M, de Franchis R, Kraus JP, Andria G. The molecular basis of homocystin- 
uria due to cystathionine beta-synthase deficiency in Italian families, and report of four novel mutations. Am J Hum Genet 1995; 56: 1324-33.

11. Tsai MY, Bignell M, Schwichtenberg K, Hanson NQ. High prevalence of a mutation in the cystathionine beta-synthase gene. Am J Hum Genet 1996; 59: 1262-7.

12. Sharp L, Little J. Polymorphisms in genes involved in folate metabolism and colorectal neoplasia: a HuGE review Am J Epidemiol 2004; 159: 423-43.

13. Pepe G, Vanegas OC, Rickards O, et al World distribution of the T833C/844INS68 CBS in cis double mutation: a reliable anthropological marker. Hum Genet 1999; 104: 126-9.

14. De Stefano V, Dekou V, Nicaud V, et al. Linkage disequilibrium at the cystathionine beta synthase (CBS) locus and the association between genetic variation at the CBS locus and plasma levels of homocysteine. The Ears II Group. European Atherosclerosis Research Study. Ann Hum Genet 1998; 62: 481-90.

15. Kluijtmans LA, Boers GH, Trijbels FJ, van Lith-Zanders HM, van den Heuvel LP, Blom HJ. A common 844INS68 insertion variant in the cystathionine beta-synthase gene. Biochem Mol Med 1997; 62: 23-5.

16. Grossmann R, Schwender S, Geisen U, Schambeck C, Merati G, Walter U. CBS 844ins68, MTHFR TT677 and EPCR 4031ins23 genotypes in patients with deep-vein thrombosis. Thromb Res 2002; 107: 13-5.

17. Urreizti R, Asteggiano C, Vilaseca MA, et al. A CBS haplotype and a polymorphism at the MSR gene are associated with cardiovascular disease in a Spanish case-control study. Clin Biochem 2007; 40: 864-8.

18. Rai PS, Murali TS, Vasudevan TG, et al. Genetic variation in genes involved in folate and drug metabolism in a south Indian population. Indian J Hum Genet 2011; 17 (Suppl. 1): 48-53.

19. Vyletal P, Sokolová J, Cooper DN, et al. Diversity of cystathionine beta-synthase haplotypes bearing the most common homocystinuria mutation c.833T>C: a possible role for gene conversion. Hum Mutat 2007; 28: 255-64.

20. Senemar S, Doroudchi M, Pezeshki AM, Bazrgar M, Torab-Jahromi A, Ghaderi A. Frequency of cystathionine beta-synthase 844INS68 polymorphism in Southern Iran. Mol Biol Rep 2009; 36: 353-6.

21. Zhang G, Dai C. Gene polymorphisms of homocysteine metabolism-related enzymes in Chinese patients with occlusive coronary artery or cerebral vascular diseases. Thromb Res 2001; 104: 187-95.

22. Gutiérrez JI, Pérez F, Tamparillas M, et al. Polymorphisms in cystathionine beta-synthase and methylene tetrahydrofolate reductase genes as risk factors for cerebral vascular disease. Med Clin 2005; 124: 281-4.

23. Guzmán N, Salazar L. Asociación de variantes funcionales en genes del metabolismo de la homocisteína con riesgo de trombosis venosa profunda e hiperhomocisteinemia en individuos del Sur de Chile. Rev Chil Cardiol 2011; 30: 28-32.

24. Speer MC, Nye J, McLone D, et al. Possible interaction of genotypes at cystathionine beta-synthase and methylenetetrahydrofolate reductase (MTHFR) in neural tube defects. NTD Collaborative Group. Clin Genet 1999; 56: 142-4

25. Alves Jacob M, da Cunha Bastos C, Regina Bonini-Domingos $C$. The 844ins68 cystathionine beta-synthase and C677T MTHFR gene polymorphism and the vaso-occlusive event risk in sickle cell disease. Arch Med Sci 2011; 7: 97-101.

26. Weiner AS, Boyarskikh UA, Voronina EN, et al. Polymorphisms in the folate-metabolizing genes MTR, MTRR, and CBS and breast cancer risk. Cancer Epidemiol Biomarkers Prev 2007; 16: 1140-7.

27. Stevens VL, McCullough ML, Pavluck AL, et al. Association of polymorphisms in one-carbon metabolism genes and postmenopausal breast cancer incidence. Cancer Epidemiol 2012; 36: 95-100.

28. Miller SA, Dykes DD, Polesky HF. A simple salting out procedure for extracting DNA from human nucleated cells. Nucleic Acids Res 1988; 6: 1215.

29. Sanguinetti CJ, Dias NE, Simpson AJ. Rapid silver staining and recovery of PCR products separated on polyacrylamide gels. Biotechniques 1994; 17: 914-21.

30. Naieni KH, Ardalan A, Mahmoodi M, Motevalian A, Yahyapoor Y, Yazdizadeh B. Risk factors of breast cancer in north of Iran: a case-control in Mazandaran Province. Asian Pac J Cancer Prev 2007; 8: 395-8.

31. Henderson BE, Roos RK, Judd HL. Regular ovulatory cycles do increase breast cancer risk? Cancer 1985; 56: 1206-8.

32. Macciò A, Madeddu C. Obesity, Inflammation, and postmenopausal breast cancer: therapeutic implications. Sci World J 2011; 11: 2020-36.

33. Chlebowski RT, Anderson GL, Gass M, et al. WHI Investigators. Estrogen plus progestin and breast cancer incidence and mortality in postmenopausal women. JAMA 2010; 304: 1684-92.

34. Collaborative Group on Hormonal Factors in Breast Cancer and hormonal contraceptives: collaborative reanalysis of data on 53297 Single Women with breast cancer and 100239 women without breast cancer from 54 epidemiological studies. Lancet 1996; 347: 1713-27.

35. Lazcano EC, Tovar V, Alonso P, Romieu I, Lopez L. Breast cancer. A historical theme, present and future. J Public Health 1996; 38: 139-52.

36. Parkin DM. Cancers attributable to reproductive factors in the UK in 2010. Br J Cancer 2011; 105 (S2): S73-6.

37. Lipworth L, Bailey R, Trichopoulos D. History of breastfeeding in relation to breast cancer risk: a review of the epidemiologic literature. J Natl Cancer Inst 2000; 92: 942-3.

38. Xue F, Willett WC, Rosner BA, Hankinson SE, Michels KB. Cigarette smoking and the Incidence of breast cancer. Arch Intern Med 2011; 171: 125-33.

39. Hwang RF, Gonzalez-Angulo AM, Yi M, et al. Low locoregional failure rates in selected breast cancer patients with tumor-positive sentinel lymph nodes who do not undergo completion axillary dissection. Cancer 2007; 110: 723-30.

40. Gallegos MP, Figuera LE, Troyo R, et al. CYP1A1 *2B and *4 polymorphisms are associated with lung cancer susceptibility in Mexican patients. Int J Biol Markers 2008; 23: 24-30.

41. Lightfoot TJ, Johnston WT, Painter D, et al. United Kingdom Childhood Cancer Study. Genetic variation in the folate metabolic pathway and risk of childhood leukemia. Blood 2010; 115: 3923-9.

42. Hosseini M, Houshmand M, Ebrahimi A. MTHFR polymorphisms and breast cancer risk. Arch Med Sci 2011; 7: 134-7.

43. Mojgan $H$, Massoud $H$, Ahmad E. ERCC1 intron 1 was associated with breast cancer risk. Arch Med Sci 2012; 8: 655-8.

44. Samulak D, Romanowicz-Makowska H, Smolarz B, et al. Association between single nucleotide polymorphisms of the DNA mismatch repair gene hMSH2 and postmenopausal breast cancer in Polish women. Prz Menopauzal 2012; 1: 9-13 
45. Griffioen PH, de Jonge R, van Zelst BD, Brouns RM, Lindemans J. Detection and allele-frequencies of the 833T.C, 844 ins68 and a novel mutation in the cystathionine b-synthase gene. Clin Chim Acta 2005; 354: 191-4.

46. Dekou V, Gudnason V, Hawe E, Miller GJ, Stansbie D, Humphries SE. Gene-environment and gene-gene interaction in the determination of plasma homocysteine levels in healthy middle-aged men. Thromb Haemost 2001; 85: 67-74.

47. Tsai MY, Yang F, Bignell M, Aras O, Hanson NQ. Relationship between plasma homocysteine concentration, the 844 ins68 variant of the cystathionine beta-synthase gene, and pyridoxal-5'-phosphate concentration. Mo Genet Metab 1999; 67: 352-6.

48. Summers CM, Hammons AL, Mitchell LE, et al. Influence of the cystathionine beta-synthase 844ins 68 and methylenetetrahydrofolatereductase $677 \mathrm{C}>T$ polymorphisms on folate and homocysteine concentrations. Eur J Hum Genet 2008; 16: 1010-3.

49. Galbiatti AL, da Silva LM, Ruiz-Cintra MT, et al. Association between 11 genetic polymorphisms in folatemetabolising genes and head and neck cancer risk. Eur J Cancer 2012; 48: 1525-53.

50. Tsai MY, Bignell M, Yang F, Welge BG, Graham KJ, Hanson NQ. Polygenic influence on plasma homocysteine: association of two prevalent mutations, the 844ins 68 of cystathionine beta-synthase and A(2756)G of methionine synthase, with lowered plasma homocysteine levels. Atherosclerosis 2000; 149: 131-7.

51. Zhu K, Williams SM. Methyl-deficient diets, methylated er genes and breast cancer: an hypothesized association. Cancer Causes Control 1998; 9: 615-20.

52. Pompella A, De Tata V, Paolicchi A, Zunino F. Expression of gamma-glutamyltransferase in cancer cells and its significance in drug resistance. Biochem Pharmacol 2006; 71: 231-8.

53. Van Hemelrijck $M$, Jassem W, Walldius G, et al. Gamma-glutamyltransferase and risk of cancer in a cohort of 545,460 persons - the Swedish AMORIS study. Eur J Cancer 2011; 47: 2033-41.

54. Fentiman IS, Allen DS. gamma-Glutamyltransferase and breast cancer risk. Br J Cancer 2010; 103: 90-3.

55. Hvidtfeldt UA, Gunter MJ, Lange T, et al. Quantifying mediating effects of endogenous estrogen and insulin in the relation between obesity, alcohol consumption, and breast cancer. Cancer Epidemiol Biomarkers Prev 2012; 21: 1203-12.

56. Mihlon F 4th, Ray CE Jr, Messersmith W. Chemotherapy agents: a primer for the interventional radiologist. Semin Intervent Radiol 2010; 27: 384-90.

57. Cao R, Wang LP. Serological diagnosis of liver metastasis in patients with breast cancer. Cancer Biol Med 2012; 9: 57-62.

58. Schiavon G, Gupta GP, Redana S, Santini D. Heterogeneity of breast cancer: gene signatures and beyond. In Diagnostic, prognostic and therapeutic value of gene signatures. Russo A, lacobelli S, lovanna J (ed.). Springer Science 2012; 13-25.

59. Ericson U, Sonestedt E, Ivarsson MI, et al. Folate intake, methylenetetrahydrofolate reductase polymorphisms, and breast cancer risk in women from the Malmo diet and cancer cohort. Cancer Epidemiol Biomarkers Prev 2009; 18: 1101-10.

60. Chen S, Chen CM, Zhou Y, Zhou RJ, Yu KD, Shao ZM. Obesity or overweight is associated with worse pathological response to neoadjuvant chemotherapy among Chinese women with breast cancer. PLoS One 2012; 7: e41380.
61. Arcidiacono B, liritano S, Nocera A, et al. Insulin resistance and cancer risk: an overview of the pathogenetic mechanisms. Exp Diabetes Res 2012; 2012: 789174.

62. Suzuki T, Matsuo K, Hirose K, et al. One-carbon metabolism-related gene polymorphisms and risk of breast cancer. Carcinogenesis 2008; 29: 356-62. 